\title{
INTERPRETING RADIOCARBON DATES FROM THE PALEOLITHIC LAYERS OF THEOPETRA CAVE IN THESSALY, GREECE
}

\author{
Yorgos Facorellis ${ }^{1}$ Panagiotis Karkanas ${ }^{2}$ Thomas Higham $^{3}$ • Fiona Brock ${ }^{3}$ Maria Ntinou ${ }^{4}$ \\ Nina Kyparissi-Apostolika²
}

\begin{abstract}
Theopetra Cave is a unique prehistoric site for Greece, as the Middle and Upper Paleolithic, Mesolithic, and Neolithic periods are present here, bridging the Pleistocene with the Holocene. During the more than $20 \mathrm{yr}$ of excavation campaigns, charcoal samples from hearths suitable for ${ }^{14} \mathrm{C}$ dating were collected from all anthropogenic layers, including the Paleolithic ones. Most of the samples were initially dated using the ABA chemical pretreatment protocol in the Laboratory of Archaeometry of NCSR Demokritos, Greece, and the Radiocarbon Dating and Cosmogenic Isotopes Laboratory of the Weizmann Institute of Science, Israel. The ${ }^{14} \mathrm{C}$ results, which were not always consistent versus depth, showed that the earliest limit of human presence is $\sim 50,000 \mathrm{yr} \mathrm{BP}$, thus reaching the age limits of the ${ }^{14} \mathrm{C}$ dating method. However, $10 \mathrm{TL}$-dated burnt flint specimens unearthed from the lower part of the Middle Paleolithic sequence of the cave gave ages ranging between $\sim 110$ and $135 \mathrm{kyr}$ ago. These results are in disagreement with the ${ }^{14} \mathrm{C}$ dates, as they support a much later date for these layers. In order to clarify the situation further, charcoal samples originating from hearths were conventionally dated in the Laboratory of Archaeometry of NCSR Demokritos using the ABA pretreatment. Additionally, hand-picked charcoal fragments also underwent ${ }^{14} \mathrm{C}$ dating by AMS in the Oxford Radiocarbon Accelerator Unit using the acid-base wet oxidation (ABOX-SC) pretreatment protocol. The ${ }^{14} \mathrm{C}$ dates from the cave's Paleolithic layers obtained by both pretreatment protocols suggest a probable charcoal diagenesis affecting the ${ }^{14} \mathrm{C}$ results of these very old samples. However, the dates obtained with ABOX-SC pretreatment are considered more reliable and in the younger stratigraphic part produced consistent results with the TL dating.
\end{abstract}

\section{INTRODUCTION}

The long-known Theopetra Cave $\left(21^{\circ} 40^{\prime} 46^{\prime \prime} \mathrm{E}, 39^{\circ} 40^{\prime} 51^{\prime \prime} \mathrm{N}\right)$ is a unique prehistoric site for Greece (Figure 1), as the Middle and Upper Paleolithic, Mesolithic, and Neolithic periods are present here, bridging the Pleistocene with the Holocene (Kyparissi-Apostolika 1998, 1999; Facorellis and Maniatis 2000; Facorellis et al. 2001).

Figure 2 shows the established $2 \times 2 \mathrm{~m}$ square excavation grids that cover the greater part of the cave. The deposits reach their thickest at $\sim 6.40 \mathrm{~m}$ in the central area of the cave, while at the periphery they reach a thickness of only 3-3.50 m. The Pleistocene deposits are quite different from the Holocene ones (maximum thickness of 4.5 and $1.5 \mathrm{~m}$, respectively). The Pleistocene sediments entered the cave partly through karstic aquifers and partly through the entrance of the cave. In particular, the sequence of Pleistocene stratigraphy is a thick sandwich of water-lain sediments with intervening deposits of numerous superimposed ashy hearths (Karkanas 1999, 2001). The upper part of the Paleolithic sequence, although represented over the whole excavated area (layers II10-II12), preserve very few recognizable Upper Paleolithic lithic artifacts. The lower part of the Middle Paleolithic sequence (I-II9) is represented by the most clearly stratified lithic assemblages, beginning with the Quina phase in the lower part of the sequence, Levallois in the middle part (Figure 3), and Levallois with an Upper Paleolithic component in the upper part (Panagopoulou 1999, 2000).

\footnotetext{
${ }^{1}$ Laboratory of Instrumental and Chemical Analysis, Faculty of Fine Arts and Design, Department of Antiquities and Works of Art Conservation, Technical Educational Institute of Athens, Aghiou Spyridonos, 12210 Egaleo, Athens, Greece. Corresponding author. Email: yfacorel@teiath.gr.

${ }^{2}$ Ephorate of Palaeoanthropology and Speleology of Southern Greece, Ardittou 34B, 11636 Athens, Greece.

${ }^{3}$ Oxford Radiocarbon Accelerator Unit, Research Laboratory for Archaeology and the History of Art, University of Oxford, Dyson Perrins Building, South Parks Rd, Oxford OX1 3QY, United Kingdom.

${ }^{4}$ TDPEAE, Scientific Committee of Nikopolis, Mytikas, Preveza, Greece.
}

(C) 2013 by the Arizona Board of Regents on behalf of the University of Arizona

Proceedings of the 21st International Radiocarbon Conference edited by A J T Jull \& C Hatté

RADIOCARBON, Vol 55, Nr 2-3, 2013, p 1432-1442 


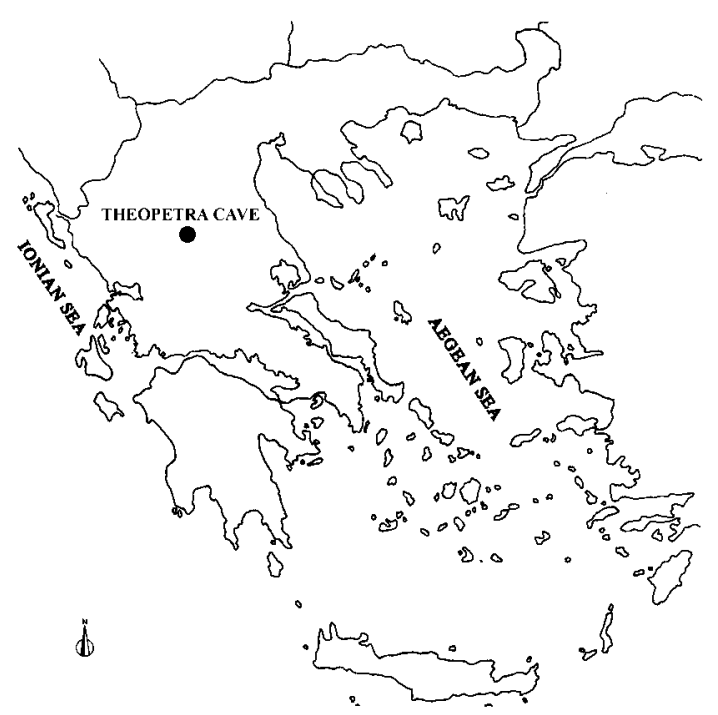

Figure 1 Map of Greece showing the location of Theopetra Cave.

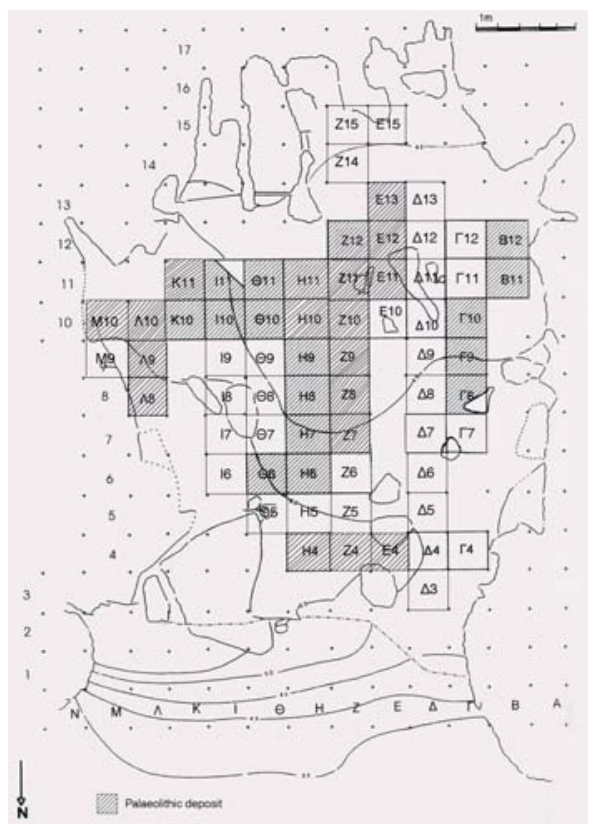

Figure 2 Plan of the cave showing the excavation grid and topographic contours at $0.5-\mathrm{m}$ intervals.

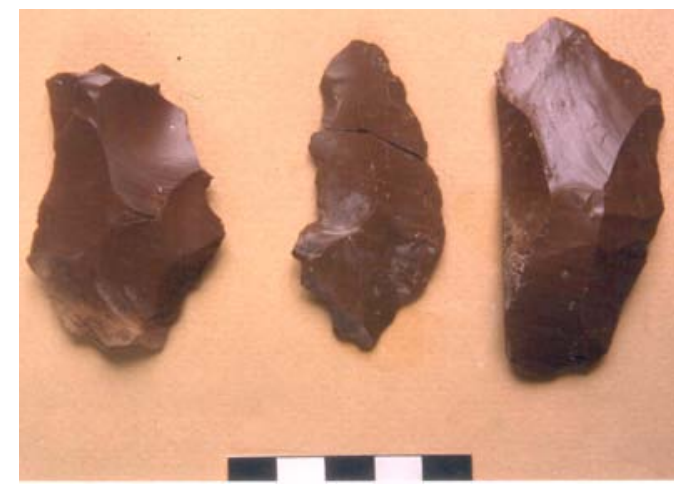

Figure 3 Middle Paleolithic tools

During the more than 20 yr of excavation campaigns under the direction of archaeologist Dr Nina Kyparissi-Apostolika, evidence of human activity, such as charcoal samples from hearths suitable for ${ }^{14} \mathrm{C}$ dating, were collected from all anthropogenic layers, including the Paleolithic ones. Initially, the ${ }^{14} \mathrm{C}$ results published by Facorellis et al. (2001) showed that the earliest limit of human presence probably exceeds 50,000 yr BP, thus reaching the age limits of the ${ }^{14} \mathrm{C}$ dating method (Facorellis and Maniatis 1999). Nevertheless, the lowest combustion layers II2 and II4 gave ${ }^{14} \mathrm{C}$ ages in the range 36-46 kyr BP. However, later on, 10 burnt flint specimens unearthed in layers II2 and II4, corresponding to the lower part of the Middle Paleolithic sequence of Theopetra Cave, were dated by the thermoluminescence (TL) method and gave ages ranging between 110 and $140 \mathrm{kyr}$ ago. Moreover, 1 burnt flint from layer II11 gave a TL age of $57 \pm 6$ kyr ago (Valladas et al. 2007). The positions of the TL-dated samples are shown in Figure 4. These results, which support a much later date for the 


\section{Interpreting ${ }^{14} \mathrm{C}$ Dates from Paleolithic Layers of Theopetra Cave}

Middle Paleolithic layers, are in disagreement with the ${ }^{14} \mathrm{C}$ dates, and question the assignment of the upper part of the sequence to the Upper Paleolithic that nevertheless was based on very few artifacts.

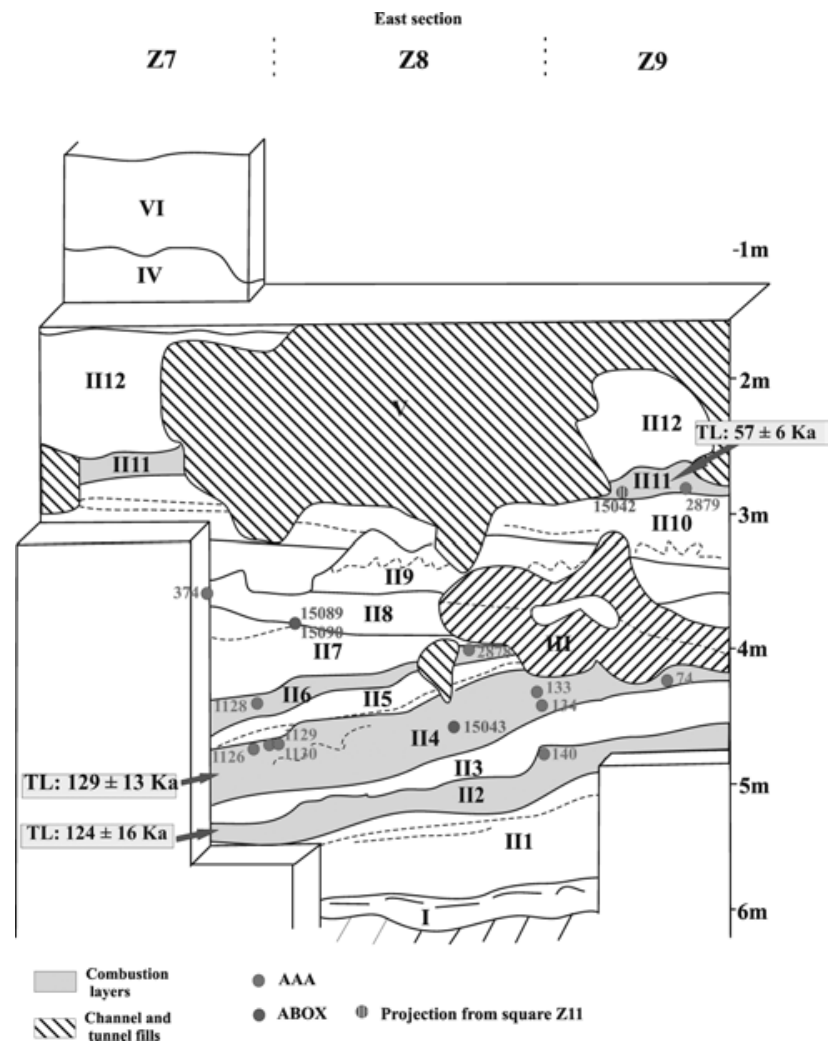

Figure 4 Stratigraphic profile Z7-Z9 showing the positions of the samples and the TL ages.

The depositional sequence of Theopetra Cave is complex with frequently appearing filled channels and underground tunnels as well as labyrinthine large burrows. Resolving the stratigraphy during excavations was very difficult, but all the above features and the thick combustion layers are distinct in appearance and can be easily followed in the excavated profiles. Therefore, in order to clarify the reason for the discrepancies with the ${ }^{14} \mathrm{C}$ ages we wanted first to eliminate the possibility of postdepositional movement of younger charcoal down the sequence by ${ }^{14} \mathrm{C}$ dating more samples, and then to find out if the charcoal was diagenetically modified. In addition, by using anthracological analysis we wanted to see if the possible diagenetic alteration affected the charcoal integrity.

\section{METHODS}

The initial group of ${ }^{14} \mathrm{C}$ dates (Facorellis et al. 2001) were derived from 7 charcoal samples (DEM374, -74, -133, -134, -140, -247 and -613) originating from hearths in the Paleolithic layers. They were dated in the Laboratory of Archaeometry of NCSR Demokritos in Athens, Greece. The removal of any carbon compounds of non-archaeological origin was performed using the acid-baseacid (ABA) chemical pretreatment protocol. This consisted of samples soaking in $4 \% \mathrm{HCl}$ solution in a water bath at $80{ }^{\circ} \mathrm{C}$ for $1 \mathrm{hr}$ to remove soil carbonates and soluble organic compounds, followed 


\section{Y Facorellis et al.}

by extraction of the humic acids with $4 \% \mathrm{NaOH}$ solution for $12 \mathrm{hr}$. The samples were then re-acidified with $4 \% \mathrm{HCl}$ in a water bath for $30 \mathrm{~min}$, washed with deionized water to $\mathrm{pH} 6$, oven-dried at $105^{\circ} \mathrm{C}$, and finally ground to fine powder. Samples were then converted to $\mathrm{CO}_{2}$ using a de Vriestype continuous combustion system (de Vries and Barendsen 1953) and after several purification stages were conventionally measured inside cylindrical gas proportional counters (Facorellis 1996; Maniatis et al. 2010). Another 3 Paleolithic charcoal samples, which also underwent ABA chemical pretreatment, were dated using liquid scintillation counting in the Radiocarbon Dating and Cosmogenic Isotopes Laboratory of the Weizmann Institute of Science in Rehovot, Israel (Karkanas et al. 1999; Karkanas 2001). The samples originate from the neighboring grid squares Z7-Z11 (Figures 5 and 6) and $\Theta 10 / 10$ (Figure 7) sorted by depth. The positions of the samples are shown in Figures 4 and 8, respectively.

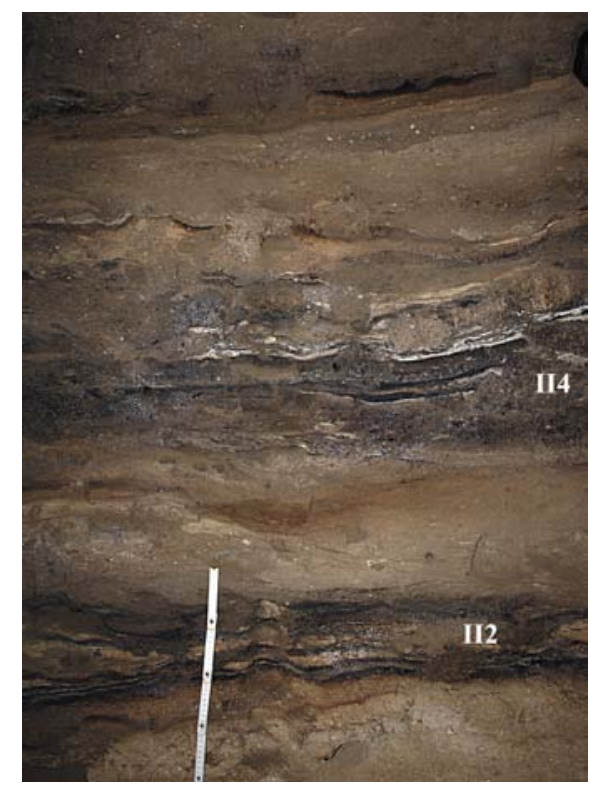

Figure 5 Stratigraphic profile of grid square Z8

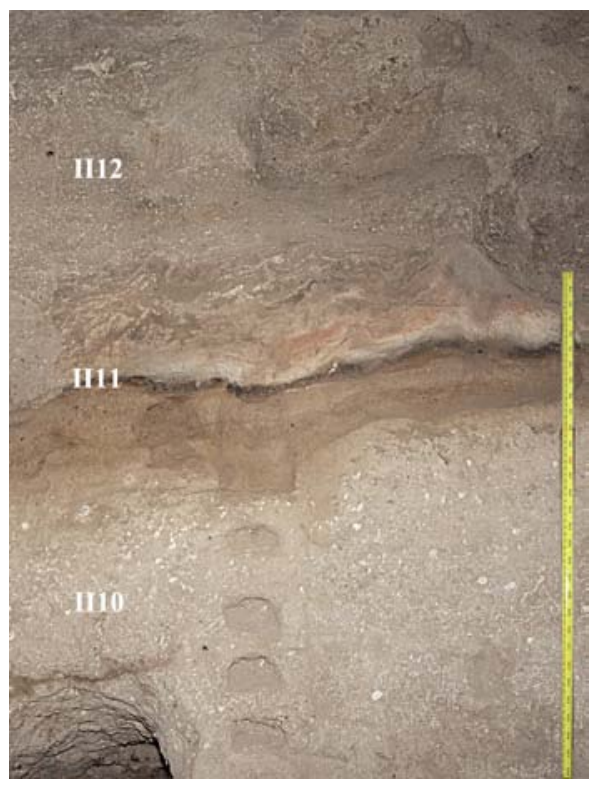

Figure 6 Stratigraphic profile of grid square Z9

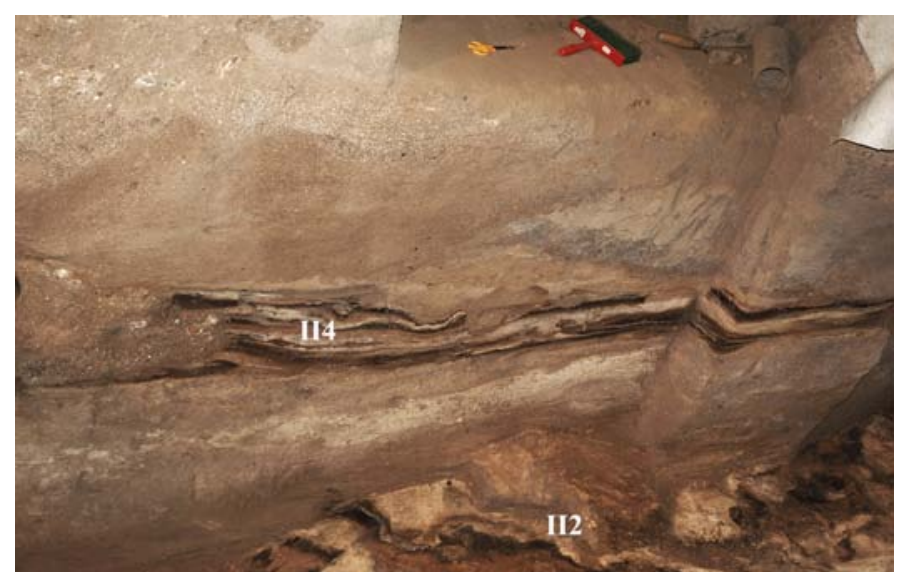

Figure 7 Stratigraphic profile of grid square $\Theta 10$ 


\section{Interpreting ${ }^{14} \mathrm{C}$ Dates from Paleolithic Layers of Theopetra Cave}

To clarify the situation further, 9 charcoal samples originating from hearths found in the layers II6, II4, and II2 of the profiles of grid squares Z7 (Figure 4; DEM-1128, -1126, -1129, and -1130) and $\Theta 10$ (Figure 8; DEM-1122, -1119, -1123, -1120 and -1121) were conventionally ${ }^{14} \mathrm{C}$ dated in the Laboratory of Archaeometry of NCSR Demokritos using the aforementioned procedure. Additionally, another 12 wood charcoal fragments were handpicked from stratigraphically secure parts of layers II2 to II11 of the profiles of grid squares Z8, Z9, and Z11 with special attention to include combustion features associated with the TL-dated samples. These charcoal samples, previously analyzed for botanical identification of the plant species (mostly Quercus sp. and Prunus sp.), were sent for accelerator mass spectrometry (AMS) dating to the Oxford Radiocarbon Accelerator Unit, where they underwent the acid-base-wet oxidation (ABOX-SC) pretreatment protocol. This method removes contaminants more efficiently than a standard ABA pretreatment and has been shown to yield significantly older dates for some samples (Bird et al. 1999, 2003; Turney et al. 2001; Santos et al. 2003; Higham et al. 2009a,b; Brock and Higham 2009). The applied pretreatment described by Brock et al. (2010) consists of the following steps. The charcoal samples were roughly crushed before being treated with $6 \mathrm{M} \mathrm{HCl}$ (room temperature, $1 \mathrm{hr}$ ), followed by $1 \mathrm{M} \mathrm{NaOH}$ (room temperature, $30 \mathrm{~min}$ ). The base may be replaced with fresh solution 1 or more times during this period if it becomes particularly dark colored. The samples were washed 3 times with ultrapure water after both treatments and then treated with $0.1 \mathrm{M}$ potassium dichromate in $2 \mathrm{M}$ sulfuric acid in a sealed tube at $60{ }^{\circ} \mathrm{C}$ for $\sim 20 \mathrm{hr}$. The remaining material (described as "oxidation resistant elemental carbon" or OREC by Bird et al. [1999]) was then rinsed 3 times with ultrapure water at $35^{\circ} \mathrm{C}$ for $5 \mathrm{~min}$ and the fine material discarded. The samples were then freeze-dried before $\sim 20 \mathrm{mg}$ was precombusted at $630{ }^{\circ} \mathrm{C}$ for $2 \mathrm{hr}$ in the presence of copper oxide ( $200 \mathrm{mg}, 4 \times 0.5 \mathrm{~mm}$ wire) and quartz wool in a sealed evacuated quartz glass tube. Prior to combustion, the copper oxide and quartz wool were heated in an evacuated sealed tube at $850{ }^{\circ} \mathrm{C}$ for $8 \mathrm{hr}$. The remaining OREC sample was then combusted and graphitized as normal for dating.

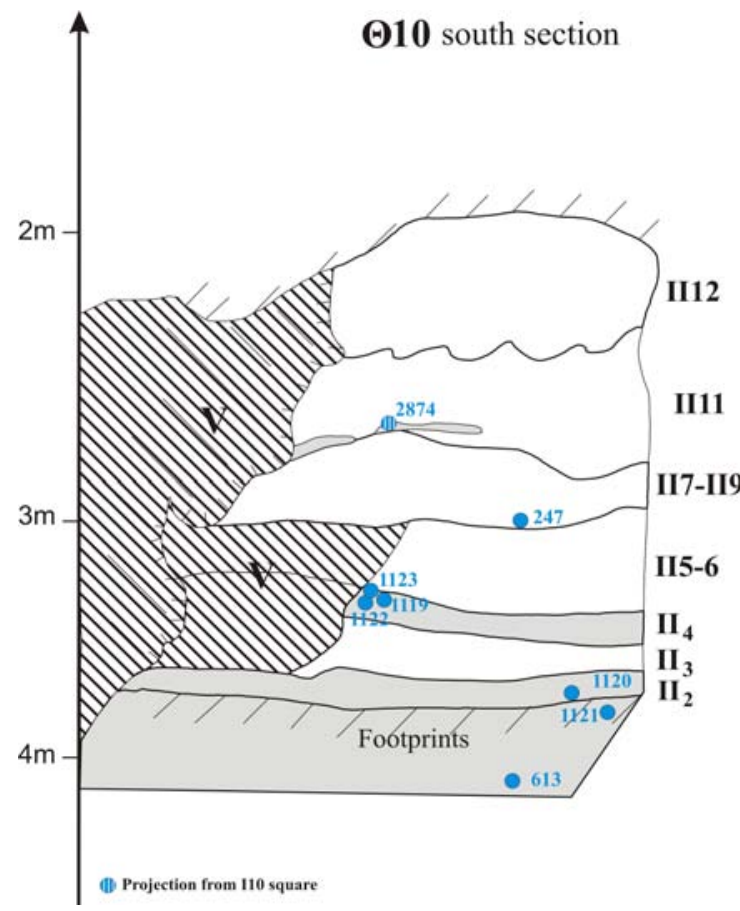

Figure 8 Stratigraphic profile $\Theta 10$ showing the positions of the samples. 


\section{Y Facorellis et al.}

\section{RESULTS AND DISCUSSION}

Table 1 presents the ${ }^{14} \mathrm{C}$ dating results produced by all 3 laboratories. Only 3 of the $12 \mathrm{ABOX}$-SC pretreated samples (OxA-15042, -15089, and -15043) produced a ${ }^{14} \mathrm{C}$ date as most of them failed in this pretreatment procedure due to low yields, 8 of them during the wet oxidation stage, which is very harsh, and 1 during the precombustion stage. These samples appeared to have been very fragile and were quickly reduced in size. In one case, the same sample was dated twice (OxA-15089: $50,100 \pm 1300 \mathrm{yr}$ BP and OxA-15090: 43,400 $\pm 1500 \mathrm{yr}$ BP). Although it was split in 2 and identically treated as part of the Oxford laboratory's autoduplicate program, undertaken in order to examine routine sample reproducibility, there is poor agreement between the 2 determinations (beyond 2 standard deviations). We argue that the older date (OxA-15089) is more reliable and free of carbon contaminants since the OxA-15090 sample was very small, and hence more susceptible to contaminants, and smaller than the normal AMS standards. Interestingly, the internal structure of the charcoal did not show indications of chemical alteration such as humification, hence its species identification. The $\delta^{13} \mathrm{C}$ values of these samples are as follows: OxA-15042: $\delta^{13} \mathrm{C}=-21.0 \%$; OxA-15043: $\delta^{13} \mathrm{C}=-24.0 \%$; OxA-15089: $\delta^{13} \mathrm{C}=-23.2 \%$; and OxA-15090: $\delta^{13} \mathrm{C}=-23.6 \%$.

Table 1 Summary of ${ }^{14} \mathrm{C}$ dating results from the Paleolithic layers of Theopetra Cave. The dates of charcoal samples from the neighboring grid squares Z7-Z11 and $\Theta 10 / 10$ are sorted by depth, reporting also the pretreatment protocol used. The positions of the samples are shown in Figures 4 and 8, respectively. ( ${ }^{*}$ Dates extend out of calibration curve range, ${ }^{* *}$ Previously published dates).

\begin{tabular}{|c|c|c|c|c|c|c|c|}
\hline Lab code & $\begin{array}{l}\text { Grid } \\
\text { square }\end{array}$ & $\begin{array}{l}\text { Strat. } \\
\text { unit-layer }\end{array}$ & $\begin{array}{l}\text { Depth } \\
\text { (m) }\end{array}$ & Age (yr BP) & $\begin{array}{l}\text { Calibrated age } \\
\text { (cal yr) }(1 \sigma, 2 \sigma)\end{array}$ & $\begin{array}{l}\text { Pretreatment } \\
\text { protocol }\end{array}$ & Reference \\
\hline OxA-15042 & Z11 & II11 & 2.70 & $45,750 \pm 750$ & $\begin{array}{l}50,000^{*}-48,480 \\
50,000^{*}-47,250\end{array}$ & ABOX-SC & \\
\hline RT-2879** & Z9 & II11 & 2.90 & $25,625 \pm 500$ & $\begin{array}{l}30,970-29,870 \\
31,130-29,530\end{array}$ & $\mathrm{ABA}$ & $\begin{array}{l}\text { Karkanas et al. } \\
1999\end{array}$ \\
\hline DEM-374** & $\mathrm{Z7}$ & II8 & $3.62-3.77$ & $32,672 \pm 1503$ & $\begin{array}{l}39,260-35,500 \\
41,270-34,810\end{array}$ & $\mathrm{ABA}$ & $\begin{array}{l}\text { Facorellis et al. } \\
2001\end{array}$ \\
\hline OxA-15090 & Z8 & II8-7 & $3.70-3.80$ & $43,400 \pm 1500$ & $\begin{array}{l}48,320-45,440 \\
49,810-44,890\end{array}$ & ABOX-SC & \\
\hline OxA-15089 & Z8 & II8-7 & $3.70-3.80$ & $50,100 \pm 1300$ & a & ABOX-SC & \\
\hline RT-2878** & $\mathrm{Z8}$ & II6 & 3.95 & $36,550 \pm 420$ & $\begin{array}{l}41,900-41,270 \\
42,250-40,950\end{array}$ & $\mathrm{ABA}$ & $\begin{array}{l}\text { Karkanas et al. } \\
1999\end{array}$ \\
\hline DEM-74** & Z9 & II4 & 4.28 & $38,079 \pm 1942$ & $\begin{array}{l}44,490-42,280 \\
47,370-39,400\end{array}$ & $\mathrm{ABA}$ & $\begin{array}{l}\text { Facorellis et al. } \\
2001\end{array}$ \\
\hline DEM-1128 & $\mathrm{Z7}$ & II6 & 4.42 & $>51,000$ & $>50,000$ & $\mathrm{ABA}$ & \\
\hline DEM-133** & Z8-Z9 & II4 & 4.39-4.49 & $39,274 \pm 4771$ & $\begin{array}{l}48,100-41,220 \\
50,000^{*}-38,940\end{array}$ & $\mathrm{ABA}$ & $\begin{array}{l}\text { Facorellis et al. } \\
2001\end{array}$ \\
\hline OxA-15043 & $\mathrm{Z} 8$ & II4 & $4.50-4.70$ & $48,000 \pm 1100$ & a & ABOX-SC & \\
\hline DEM-134** & Z8-Z9 & II4 & 4.55 & $36,827 \pm 845$ & $\begin{array}{l}42,410-41,150 \\
43,170-40,370\end{array}$ & $\mathrm{ABA}$ & $\begin{array}{l}\text { Facorellis et al. } \\
2001\end{array}$ \\
\hline DEM-1126 & $\mathrm{Z7}$ & II4 & $4.56-4.69$ & $50,180 \pm 1500$ & & $\mathrm{ABA}$ & \\
\hline DEM-1129 & $\mathrm{Z7}$ & II 4 & $4.64-4.70$ & $>50,000$ & $>50,000$ & $\mathrm{ABA}$ & \\
\hline DEM-1130 & $\mathrm{Z7}$ & II4 & $4.64-4.70$ & $>50,000$ & $>50,000$ & $\mathrm{ABA}$ & \\
\hline DEM-140** & $\mathrm{Z8}$ & II2 & 4.80 & $39,414 \pm 3914$ & $\begin{array}{l}47,520-41,420 \\
50,000^{*}-39,740\end{array}$ & $\mathrm{ABA}$ & $\begin{array}{l}\text { Facorellis et al. } \\
2001\end{array}$ \\
\hline RT-2874** & I10 & II11 & 2.52 & $25,820 \pm 270$ & $\begin{array}{l}30,880-30,400 \\
31,110-30,210\end{array}$ & $\mathrm{ABA}$ & $\begin{array}{l}\text { Karkanas et al. } \\
1999\end{array}$ \\
\hline DEM-247** & 10 & II7-9 & 3.03 & $33,085 \pm 1573$ & $\begin{array}{l}40,010-36,400 \\
41,690-35,010\end{array}$ & ABA & $\begin{array}{l}\text { Facorellis et al. } \\
2001\end{array}$ \\
\hline DEM-1122 & 10 & II4 & 3.31-3.34 & $40,030 \pm 750$ & $\begin{array}{l}44,570-43,400 \\
45,210-42,900\end{array}$ & $\mathrm{ABA}$ & \\
\hline
\end{tabular}




\section{Interpreting ${ }^{14} \mathrm{C}$ Dates from Paleolithic Layers of Theopetra Cave}

Table 1 Summary of ${ }^{14} \mathrm{C}$ dating results from the Paleolithic layers of Theopetra Cave. The dates of charcoal samples from the neighboring grid squares Z7-Z11 and $\Theta 10 / 10$ are sorted by depth, reporting also the pretreatment protocol used. The positions of the samples are shown in Figures 4 and 8, respectively. ( ${ }^{*}$ Dates extend out of calibration curve range, ${ }^{* *}$ Previously published dates). (Continued)

\begin{tabular}{|c|c|c|c|c|c|c|c|}
\hline Lab code & $\begin{array}{l}\text { Grid } \\
\text { square }\end{array}$ & $\begin{array}{l}\text { Strat. } \\
\text { unit-layer }\end{array}$ & $\begin{array}{l}\text { Depth } \\
\text { (m) }\end{array}$ & Age (yr BP) & $\begin{array}{l}\text { Calibrated age } \\
\text { (cal yr) }(1 \sigma, 2 \sigma)\end{array}$ & $\begin{array}{l}\text { Pretreatment } \\
\text { protocol }\end{array}$ & Reference \\
\hline DEM-1119 & 10 & II4 & $3.28-3.34$ & $45,803 \pm 1200$ & $\begin{array}{l}50,000^{*}-48,080 \\
50,000^{*}-46,760\end{array}$ & $\mathrm{ABA}$ & \\
\hline DEM-1123 & 10 & II4 & 3.35 & $44,369 \pm 1539$ & $\begin{array}{l}49,020-46,280 \\
50,000^{*}-45,670\end{array}$ & ABA & \\
\hline DEM-1120 & 10 & II2 & $3.52-3.68$ & $43,294 \pm 1000$ & $\begin{array}{l}47,600-45,460 \\
49,180-45,020\end{array}$ & $\mathrm{ABA}$ & \\
\hline DEM-1121 & 10 & II2 & $3.57-3.66$ & $43,420 \pm 2000$ & $\begin{array}{l}48,660-45,350 \\
50,000^{*}-44,710\end{array}$ & ABA & \\
\hline DEM-613** & 10 & II2 & $4.07-4.17$ & $46,327 \pm 1590$ & $\begin{array}{l}50,000^{*}-48,110 \\
50,000^{*}-46,700\end{array}$ & ABA & $\begin{array}{l}\text { Facorellis et al. } \\
2001\end{array}$ \\
\hline
\end{tabular}

a Date out of calibration range.

The conventional ${ }^{14} \mathrm{C}$ ages were calibrated with the IntCal09 calibration curve (Reimer et al. 2009) using OxCal v 4.1.7 software (Bronk Ramsey 2009) (Table 1). Figures 9 and 10 present the probability distribution plots of the calibrated dates, wherever this was possible, from the grid squares Z7Z11 and $\Theta 10 / 110$, respectively, sorted by depth. Some dates appear truncated at 50,000 cal yr BP as they extend beyond the range of the calibration curve. The dates shown in gray and black correspond to those produced using the $\mathrm{ABA}$ and $\mathrm{ABOX}-\mathrm{SC}$ chemical pretreatment protocols, respectively. Figure 11 presents bar plots of the uncalibrated ${ }^{14} \mathrm{C}$ ages from grid squares Z7-Z11 (see Figures 4, 5, and 6) and $\Theta 10 / \mathrm{I} 10$ (see Figures 7 and 8) versus depth. Similarly, the gray and black bars correspond to ages produced using the ABA and ABOX-SC chemical pretreatment protocol, respectively. The closed and open bars represent 1 and 2 standard deviations, respectively. The samples (DEM-1128, -1129, and -1130) shown with dashed bars gave background measurements. In several instances, there is no consistency of the obtained ABA ages originating from the same square versus depth (Figure 11). In Table 1 and Figure 11, one can see that the ages of the samples from grid squares Z7-Z11 dated at the Oxford AMS facility produced by the ABOX-SC pretreatment protocol are consistently older in relation to their depth and closer to the limit of the ${ }^{14} \mathrm{C}$ dating method than those produced by the ABA method, and so they may be considered as more reliable.

According to the TL date (57 $\pm 6 \mathrm{ka}$ ) of layer II11 (Figure 4) all charcoal samples originating from layers II11 and below should have produced results beyond the ${ }^{14} \mathrm{C}$ dating method limit, but instead, as mentioned above, only 3 samples gave background measurement. However, the age of the ABOX sample OxA-15042 that originates from this layer (11) overlaps within 2 standard deviations with the aforementioned TL date. The fact that the ABA pretreated samples produce younger ages than the ABOX-SC pretreated ones is evidence that they are contaminated with more recent carbon. This contamination can be very important as it is for instance in the case of the samples RT-2879 and OxA-15042, both originating from layer II11 (Figure 4), producing an age difference of $\sim 20,000 \mathrm{yr}$ (RT-2879: 25,625 \pm 500 and OxA-15042: 45,750 \pm 750 yr BP).

Although 3 of the charcoal samples from the lower layers II2 and II4 that TL dated to 110-140 kyr ago failed in the ABOX-SC pretreatment procedure, 1 sample from layer II4 gave an age of $48,000 \pm 1000$ yr BP (OxA-15043). We note that the sample is located $1.8 \mathrm{~m}$ below sample OxA15042 coming from layer II11 and dated to $45,750 \pm 750 \mathrm{yr}$ BP (Figure 4). The paleoenvironmental data of Theopetra Cave based on charcoal and phytolith analysis (Ntinou and Kyparissi-Apostolika 


\section{Y Facorellis et al.}

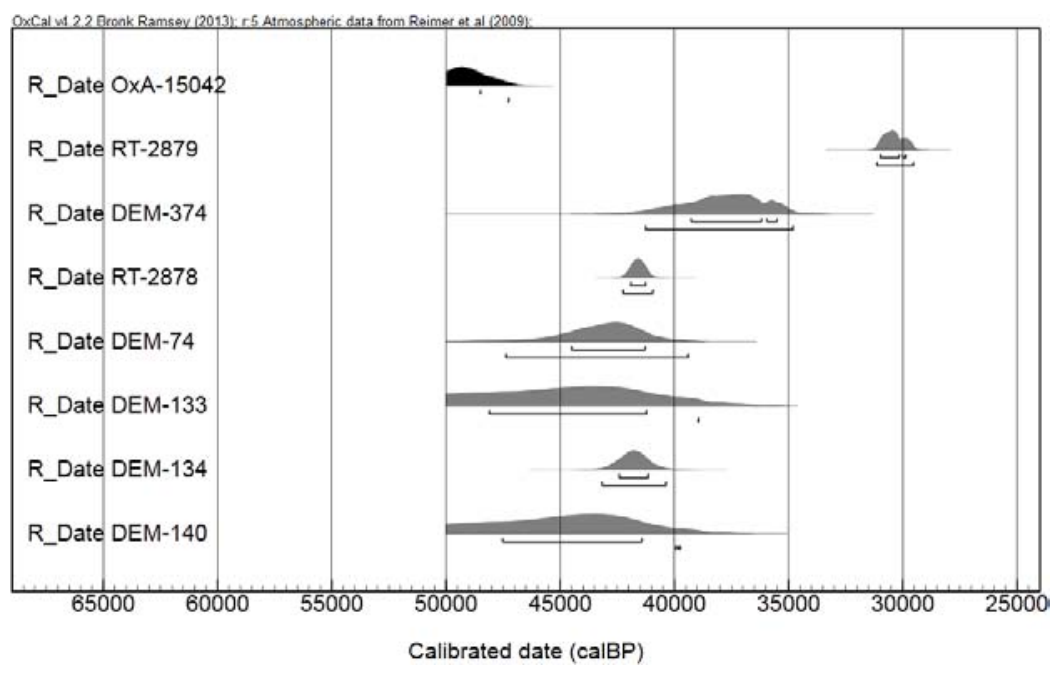

Figure 9 Probability distribution plot of the calibrated dates from the grid squares Z7-Z11 sorted by depth (see Figures 4, 5, and 6). The dates shown in gray and black correspond to those produced using the $\mathrm{ABA}$ and $\mathrm{ABOX}-\mathrm{SC}$ chemical pretreatment protocols, respectively. Dates truncated at 50,000 cal yr BP extend beyond the range of the calibration curve.

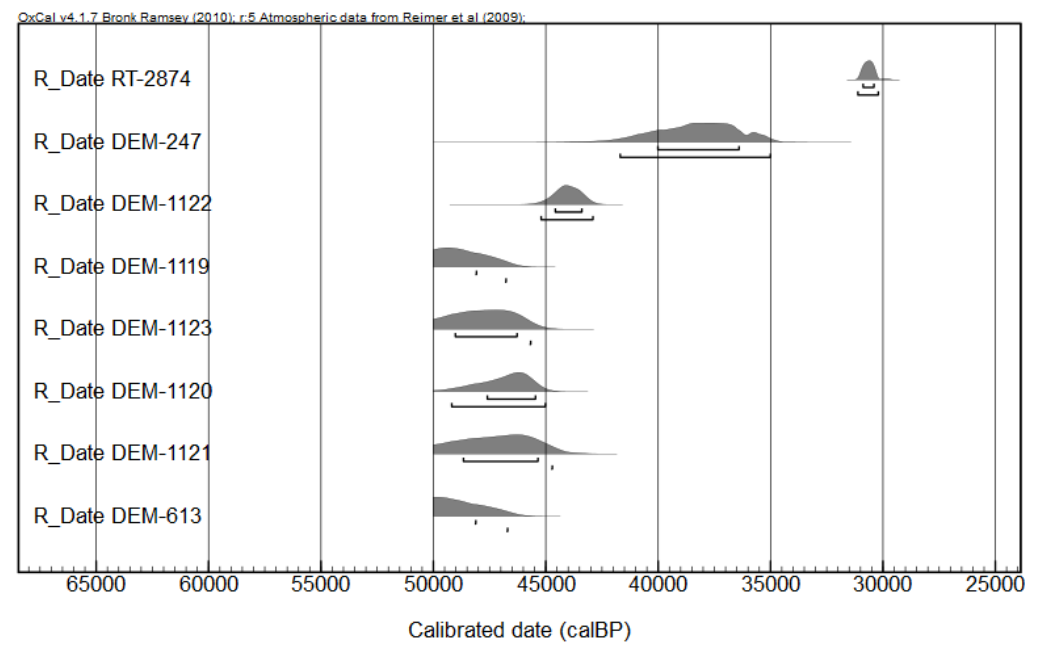

Figure 10 Probability distribution plot of the calibrated dates from grid squares $\Theta 10$ and I10 sorted by depth produced using the ABA chemical pretreatment protocol (see Figures 7 and 8). Dates truncated at 50,000 cal yr BP extend beyond the range of the calibration curve.

2008; Tsartsidou 2013) show that layers II2-II7 are associated with warm interglacial conditions followed by harsh cold climatic conditions in layers II8-II12 also characterized by intensive freezethaw activity (Karkanas 2001). Layer II11 represents slightly milder conditions probably associated with an interstadial. Therefore, given the stratigraphic position and paleoenvironmental data it is highly unlikely that layer II4 could be of the same age as layer II11, as the ${ }^{14} \mathrm{C}$ age of sample OxA15043 suggests. In this line of evidence, the TL dates of layers II2-II4 are more consistent with the paleoenvironmental analysis than the age of sample OxA-15043. 
Interpreting ${ }^{14} \mathrm{C}$ Dates from Paleolithic Layers of Theopetra Cave

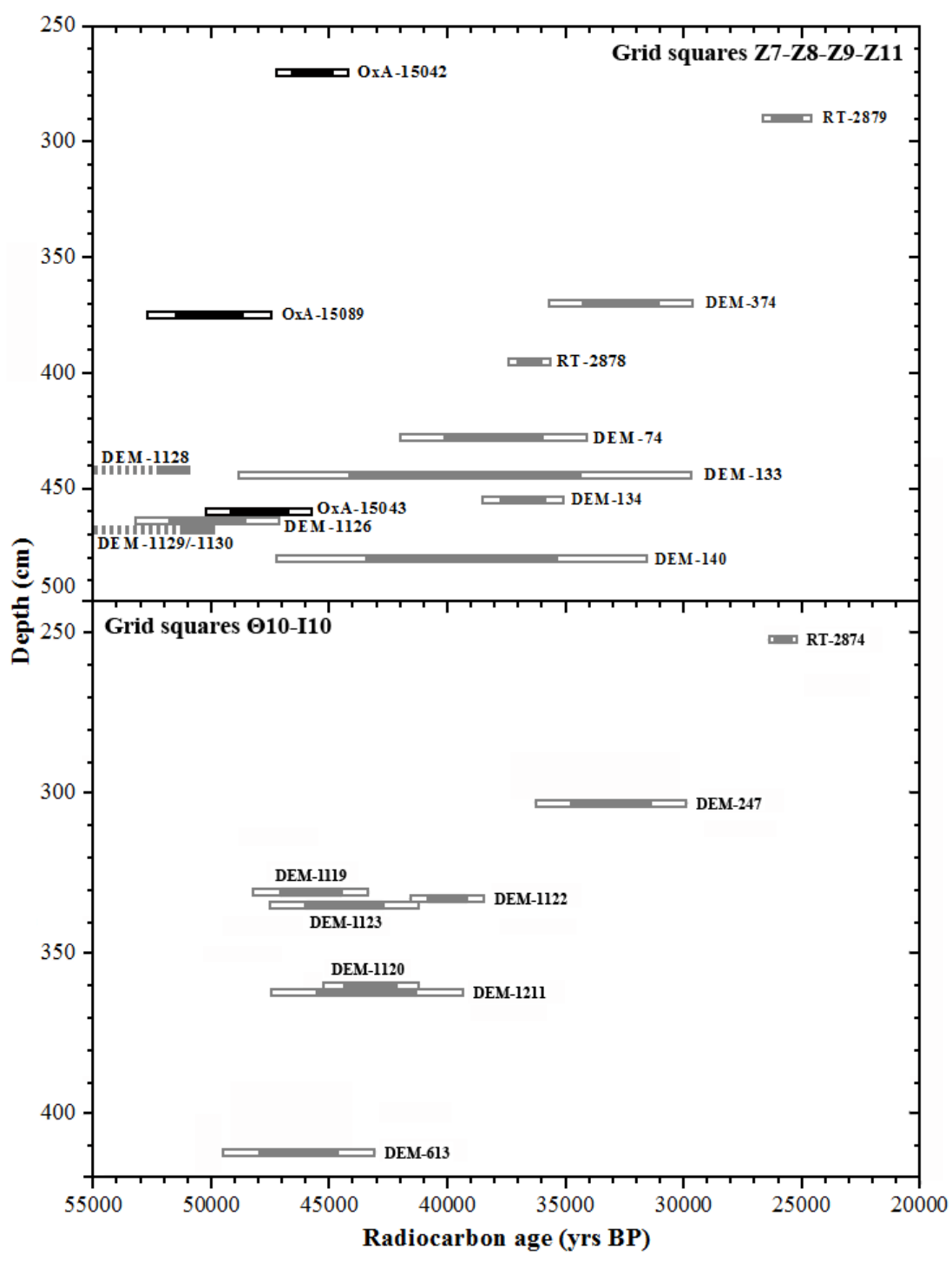

Figure 11 Bar plot of the uncalibrated ${ }^{14} \mathrm{C}$ ages from grid squares Z7-Z11 (see Figures 4, 5, and 6) and $\Theta 10-\mathrm{I} 10$ (see Figures 7 and 8) versus depth. The gray and black bars correspond to ages produced using the ABA and ABOX-SC pretreatment, respectively. The closed and open bars represent 1 and 2 standard deviations, respectively. The samples shown with dashed bars gave background measurements.

Consequently, the aforementioned analytical data raise questions about these very old charcoal samples' integrity and homogeneity, suggesting possible contamination with exogeneous carbon through diagenesis (Alon et al. 2002; Cohen-Ofri et al. 2006, 2007; Ascough et al. 2011). It is well established by sediment micromorphological analysis that the Pleistocene sediments underwent an intense diagenetic mechanical and chemical alteration related to the cave's hydrological regime. More specifically, the amount of phosphates increased during cold episodes in the cave also affected the underlying deposits. These phosphatization episodes have strongly cemented the sediments, which are characterized by the presence of the phosphate minerals leucophosphite, taranakite, and 


\section{Y Facorellis et al.}

variscite, which are known to form in low-pH environments and are probably caused by the accumulation of large amounts of guano in the cave (Karkanas 1999, 2001), which eventually could have been a possible source of the charcoal's organic contaminants. Nevertheless, it appears that the ABOX-SC pretreatment protocol was able to eliminate most of this contamination and produce ages that are more reliable particularly in the stratigraphically younger layers.

\section{CONCLUSIONS}

Twenty-three charcoal samples originating from hearths excavated in the Pleistocene layers of Theopetra Cave were ${ }^{14} \mathrm{C}$ dated by 3 different ${ }^{14} \mathrm{C}$ laboratories (Laboratory of Archaeometry of NCSR Demokritos in Athens, Greece; Radiocarbon Dating and Cosmogenic Isotopes Laboratory of the Weizmann Institute of Science in Rehovot, Israel; Oxford Radiocarbon Accelerator Unit, UK) using the ABA and the ABOX-SC pretreatment protocols. Comparison between the combined ${ }^{14} \mathrm{C}$ dates with the much older TL dates of 11 burnt flint specimens from the lower part of the Middle Paleolithic sequence indicates that most of the charcoal samples have been contaminated by a progressively increasing versus depth unidentified amount of exogeneous carbon thus yielding more recent dates. This is most probably attributed to the severe chemical alteration of the cave's Paleolithic layers that caused charcoal diagenesis affecting the ${ }^{14} \mathrm{C}$ results of these very old samples. Diagenesis seems not to have had any visible effect in the microscopic structure of charcoal. However, the ${ }^{14} \mathrm{C}$ dates obtained with the ABOX-SC protocol are more reliable and in the younger stratigraphic part of the cave are more consistent with the TL results.

\section{REFERENCES}

Alon D, Mintz G, Cohen I, Weiner S, Boaretto E. 2002. The use of Raman spectroscopy to monitor the removal of humic substances from charcoal: quality control for ${ }^{14} \mathrm{C}$ dating of charcoal. Radiocarbon $44(1)$ : $1-11$.

Ascough PL, Bird MI, Francis SM, Thornton B, Midwood AJ, Scott AC, Apperley D. 2011. Variability in oxidative degradation of charcoal: influence of production conditions and environmental exposure. Geochimica et Cosmochimica Acta 75(9):2361-78.

Bird MI, Ayliffe LK, Fifield LK, Turney CSM, Cresswell RG, Barrows TT, David B. 1999. Radiocarbon dating of "old" charcoal using a wet oxidation, stepped-combustion procedure. Radiocarbon 41(2):127-40.

Bird MI, Fifield LK, Santos GM, Beaumont PB, Zhou Y, di Tada ML, Hausladen PA. 2003. Radiocarbon dating from 40 to $60 \mathrm{ka} \mathrm{BP}$ at Border Cave, South Africa. Quaternary Science Reviews 22(8-9):943-7.

Brock F, Higham TFG. 2009. AMS radiocarbon dating of Paleolithic-aged charcoal from Europe and the Mediterranean Rim using ABOX-SC. Radiocarbon 51(2): 839-46.

Brock F, Higham T, Ditchfield P, Bronk Ramsey C. 2010. Current pretreatment methods for AMS radiocarbon dating at the Oxford Radiocarbon Accelerator Unit (ORAU). Radiocarbon 52(1):103-12.

Bronk Ramsey C. 2009. Bayesian analysis of radiocarbon dates. Radiocarbon 51(1):337-60.

Cohen-Ofri I, Weiner L, Boaretto E, Mintz G, Weiner S. 2006. Modern and fossil charcoal: aspects of structure and diagenesis. Journal of Archaeological Science 33(3):428-39.

Cohen-Ofri I, Popovitz-Biro R, Weiner S. 2007. Structural characterization of modern and fossilized charcoal produced in natural fires as determined by using electron energy loss spectroscopy. Chemistry - A European Journal 13(8):2306-10.

de Vries H, Barendsen GW. 1953. Radio-carbon dating by a proportional counter filled with carbon dioxide: Physica 19:987-1003.

Facorellis Y. 1996. Study of the conditions and the parameters for high precision dating with ${ }^{14} \mathrm{C}[\mathrm{PhD}$ thesis]. University of Patras.

Facorellis Y, Maniatis Y. 1999. The potential and accuracy of radiocarbon dating in the Palaeolithic period. In: Adam E, Bailey G, Panagopoulou E, Perles C, Zachos K, editors. The Palaeolithic Archaeology of Greece and Adjacent Areas. Proceedings of the ICOPAG Conference, Ioannina, September 1994. London: British School at Athens Studies 3. p 179-89.

Facorellis Y, Maniatis Y. 2000. ${ }^{14} \mathrm{C}$ evidence of 50,000 years of human presence in the cave of Theopetra. In: In: Kyparissi-Apostolika N, editor. Proceedings of the International Conference "The Cave of Theopetra Twelve Years of Excavations and Research," 6-7 November 1998, Trikala, Greece. Athens. p 53-68.

Facorellis Y, Kyparissi-Apostolika N, Maniatis Y. 2001. The cave of Theopetra, Kalambaka: radiocarbon evidence for 50,000 years of human presence. Radiocarbon 43(2B):975-94. 


\section{Interpreting ${ }^{14} \mathrm{C}$ Dates from Paleolithic Layers of Theopetra Cave}

Higham TFG, Barton H, Turney CSM, Barker G, Bronk Ramsey C, Brock F. 2009a. Radiocarbon dating of charcoal from tropical sequences: results from the Niah Great Cave, Sarawak and their broader implication. Journal of Quaternary Science 24(2):189-97.

Higham TFG, Brock F, Peresani M, Broglio A, Wood R, Douka K. 2009b. Problems with radiocarbon dating the Middle to Upper Palaeolithic transition in Italy. Quaternary Science Reviews 28(13-14):1257-67.

Karkanas P. 1999. Lithostratigraphy and micromorphology of Theopetra cave deposits, Thessaly, Greece: some preliminary results. In: Adam E, Bailey G, Panagopoulou E, Perles C, Zachos K, editors. The Palaeolithic Archaeology of Greece and Adjacent Areas. Proceedings of the ICOPAG Conference, Ioannina, September 1994. London: British School at Athens Studies 3. p 240-51.

Karkanas P. 2001. Site formation processes in Theopetra cave: a record of climatic change during the Late Pleistocene and Early Holocene in Thessaly, Greece. Geoarchaeology 16(4):373-99.

Karkanas P, Kyparissi-Apostolika N, Bar-Yosef O, Weiner S. 1999. Mineral assemblages in theopetra, greece: a framework for understanding diagenesis in a prehistoric cave. Journal of Archaeological Science 26(9):1171-80.

Kyparissi-Apostolika N. 1998. The significance of Theopetra cave for Greek prehistory. In: Otte M, editor. Préhistoire d' Anatolie Genèse de deux mondes. Actes du colloque international, Liège, 28 April-3 May 1997. ERAUL 85 p 241-52.

Kyparissi-Apostolika N. 1999. The Palaeolithic deposits of Theopetra Cave in Thessaly (Greece). In: Adam E, Bailey G, Panagopoulou E, Perles C, Zachos K, editors. The Palaeolithic Archaeology of Greece and Adjacent Areas. Proceedings of the ICOPAG Conference, Ioannina, September 1994. London: British School at Athens Studies 3. p 232-9.

Maniatis Y, Malamidou D, Koukouli-Chryssanthaki H, Facorellis Y. 2010. Radiocarbon dating of the Amphipolis bridge in northern Greece, maintained and functioned for 2500 years. Radiocarbon 52(1):41-63.

Ntinou M, Kyparissi-Apostolika N. 2008. The Pleistocene-Holocene charcoal record from Theopetra cave, Thessaly, Greece: implications for vegetation, climate and human use. In: Damblon F, Court-Picon M, editors. Charcoal and Microcharcoal. Continental and Marine Records. Abstracts and Programme 4th
International Meeting of Anthracology, Brussels 8-13 September 2008, Geological Survey of Belgium Professional Papers 303-2008/1. p 105.

Panagopoulou E. 1999. The Theopetra Middle Palaeolithic assemblages: their relevance to the Middle Palaeolithic of Greece and adjacent areas. In: Adam E, Bailey G, Panagopoulou E, Perles C, Zachos K, editors. The Palaeolithic Archaeology of Greece and Adjacent Areas. Proceedings of the ICOPAG Conference, Ioannina, September 1994. London: British School at Athens Studies 3. p 252-65.

Panagopoulou E. 2000. The Middle Palaeolithic lithic assemblages of Theopetra Cave: technological evolution in the Upper Pleistocene. In: Kyparissi-Apostolika $\mathrm{N}$, editor. Proceedings of the International Conference "The Cave of Theopetra - Twelve Years of Excavations and Research," 6-7 November 1998, Trikala, Greece. p 139-62.

Reimer PJ, Baillie MGL, Bard E, Bayliss A, Beck JW, Blackwell PG, Bronk Ramsey C, Buck CE, Burr GS, Edwards RL, Friedrich M, Grootes PM, Guilderson TP, Hajdas I, Heaton T, Hogg AG, Hughen KA, Kaiser KF, Kromer B, McCormac FG, Manning SW, Reimer RW, Richards DA, Southon JR, Talamo S, Turney CSM, van der Plicht J, Weyhenmeyer CE. 2009. IntCal09 and Marine09 radiocarbon age calibration curves, 0-50,000 years cal BP. Radiocarbon 51(4): 1111-50.

Santos GM, Bird MI, Fifield LK, Parenti F, Guidon N, Hausladen PA. 2003. The controversial antiquity of the peopling of the Americas: a review of the chronology of the lowest occupation layer in the Pedra Furada Rock Shelter, Piauí, Brazil. Quaternary Science Reviews 22(21-22):2303-10.

Tsartsidou G. 2013. Flora and people at the Paleolithic Cave of Theopetra, Thessaly, Greece. Presented at the $114^{\text {th }}$ International Meeting of the Archaeological Institute of America. Seattle 3-6 January 2013.

Turney CSM, Bird MI, Fifield LK, Roberts RG, Smith M, Dortch CE, Grün R, Lawson E, Ayliffe LK, Miller GH, Dortch J, Cresswell RG. 2001. Early human occupation at Devil's Lair, Southwestern Australia 50,000 years ago. Quaternary Research 55(1):3-13.

Valladas H, Mercier N, Froget L, Joron J-L, Reyss J-L, Karkanas P, Panagopoulou E, Kyparissi-Apostolika N. 2007. TL age-estimates for the Middle Palaeolithic layers at Theopetra cave (Greece). Quaternary Geochronology 2(1-4):303-8. 